\title{
The mission and purposes of the public library
}

'The public library, the local gateway to knowledge, provides a basic condition for lifelong learning, independent decision-making and cultural development of the individual and social groups.'

(IFLA/UNESCO Public Library Manifesto, 1994)

\subsection{Introduction}

This chapter is a general statement on the mission (as defined and mandated by IFLA/UNESCO 1994, Appendix 1) and purpose of the public library. The key issues reviewed are developed in greater detail in later chapters.

\subsection{Defining the public library}

Public libraries are a world-wide phenomenon. Libraries occur in a variety of societies, in differing cultures and at different stages of development. Although the varied contexts in which libraries operate inevitably result in differences in the services provided, and the way those services are delivered, libraries normally have characteristics in common, which can be defined as follows.

A public library is an organisation established, supported and funded by the community, either through local, regional or national government or through some other form of community organisation. It provides access to knowledge, information, lifelong learning, and works of the imagination through a range of resources and services and is equally available to all members of the community regardless of race, nationality, age, gender, religion, language, disability, economic and employment status and educational attainment. 


\subsection{The purposes of the public library}

The primary purpose of the public library is to provide resources and services in a variety of media to meet the needs of individuals and groups for education, information and personal development including recreation and leisure. They have an important role in the development and maintenance of a democratic society by giving the individual access to a wide and varied range of knowledge, ideas and opinions.

- The Council for Public Libraries initiated a new vision statement for Finnish public libraries, "The Library is a meeting place of people and ideas. Library: Inspiring, Surprising, Empowering."

- The Guidelines and Standards for Queensland Public Libraries were designed to improve current procedures and provide achievable goals for the public libraries in Queensland, Australia. The standards are seen as a guide towards achieving 'best practice' for those responsible for the management of public library services (see Appendix 6).

<http://www.slq.qld.gov.au/info/publib/build/standards.>

\subsubsection{Education}

'Supporting both individual and self conducted education as well as formal education at all levels.'

(Manifesto)

The need for an agency available to all, which provides access to knowledge in printed and other formats such as multimedia and Internet sources, to support formal and informal education, has been the reason for the foundation and maintenance of most public libraries and remains a core purpose for the public library. Throughout their lives people require education either at formal institutions, for example, schools, colleges and universities, or in a less formal context related to their employment and daily life. Learning does not end with the completion of formal education but is, for most people, a lifelong activity. In an increasingly complex society people will need to acquire new skills at various stages of their life. The public library has an important role in assisting this process. 
The public library should provide material in the appropriate media to support formal and informal learning processes. It should also help the customer to make use of these learning resources effectively as well as providing facilities that enable people to study. The ability to access information and make effective use of it is vital to successful education and, where possible, public libraries should co-operate with other educational organisations in teaching the use of information resources. Where adequate library facilities exist to support formal education the public library should complement these.

The public library should also actively support literacy and information literacy campaigns and training, as literacy is the key to education and knowledge and to the use of libraries and information services. Newly literate people need easy access to appropriate information materials and services to maintain and develop their skills.

In some countries the need for educational development is seen to be paramount and the focus of public libraries is to support formal education. There are, however, a variety of ways in which public libraries can support both formal and informal education. How this is achieved will depend on the local context and the level of available resources.

- In Singapore the stated mission for public library service is "to provide trusted, accessible, globally-connected, library and information service so as to promote a knowlegeable and engaged society."

- In South Africa, where many people have inadequate living space and no electricity to enable them to study, public libraries have prioritised provision of the basic facilities, artificial light, and tables and chairs.

- In some countries, libraries are required to fulfil multi-functions e.g., of both public and school libraries. In England, a smaller branch library is combined with a larger school library and located within a leisure facility. In the USA, college and public libraries are sometimes combined, such as the Central Library in San Jose, CA and Harris County Library in Tomball, TX. $<$ http://www.hcpl.net/location/tomball-college-communitylibrary>

- In Amazonas State, Venezuela, where there are few school libraries, rural libraries concentrate on providing support for students and teachers. 
- In Barcelona province, Spain, some library services offer support to distance learning students from the Open University in Catalonia.

- In the State of Queensland, Australia, the Gold Coast City Council Mobile Library visits geographically isolated primary schools.

- Norwegian libraries established quality-controlled internet sites with indexed links to resources suitable for education on different age levels. <http://detektor.deichman.no/>

- Large urban libraries like the Queens Borough Public Library in New York, USA and the Copenhagen Public Library in Denmark offer customers specially designed learning centres in their buildings. These centres include staff that provides instructional assistance with educational materials and computers.

- Russian Astrakhan Regional Children's Library communicates with young readers online. Incoming questions are referred to appropriate departments with the goal of processing requests within 24 hours. Those residing far from the library can now receive necessary books or magazines.

<http://www.goroganin.info/index.php?id_a=733>

- Entrelibros (Between books) is a net of customers and books promoted by the Autonomous Government of Extremadura, Spain. <http://plataformadelectores.org>

- In the State of Queensland, Australia, public libraries provide homework resources and support to upper primary and secondary school children through organised homework clubs in libraries. Electronic homework support is also available. <http://netlinks.slq.qld.gov.au/>

\subsubsection{Information}

'The public library is the local centre of information making all kinds of knowledge and information readily available to its users.'

(Manifesto)

It is a basic human right to be able to have access to and an understanding of information, and there is now more information available than ever before in the world's history. As a public service open to all, the public library has a key role in collecting, organizing and exploiting information, as well as providing access to a wide range of information sources. The public library has a particular responsibility to collect local 
information and make it readily available. It also acts as a memory of the past by collecting, conserving and providing access to material relating to the history of the community and of individuals. In providing a wide range of information the public library assists the community in informed debate and decision-making on key issues. In collecting and providing information the public library should, wherever possible, cooperate with other agencies to make the best use of available resources.

The rapid growth in the volume of available information and the continuing technological changes, which have radically affected the way information is accessed, have already had significant effect on public libraries and their services. Information is very important to the development of the individual and of society, and information technology gives considerable power to those able to access and use it. Despite its rapid growth it is not available to many of the world's populations, and the gap between the information rich and the information poor continues to widen in some areas. Sources of widespread public information such as television broadcasting, telephone, and other mobile web based services, educational institutions and public libraries are taken for granted in developed countries. In developing countries, however, such infrastructure is seriously deficient, and this hinders individual ability to gather information and solve problems. The Internet promises improvements to internal communications in and among developing countries. Public libraries play a role in this and must bridge that gap by providing widespread public access to the Internet (when technologically possible) as well as continuing to provide information in traditional formats. Public libraries should recognise and exploit the opportunities provided by the continued and increasing developments in information and communications technology. Public libraries continue to provide an important access point to online information services.

- Some public libraries in South Africa provide space for information kiosks and telecentres.

- Rural multi-purpose community telecentres established in 5 African countries (Benin, Mali, Mozambique, Tanzania and Uganda) provide access to modern information and communication tools.

- The public library in Memphis, TN, USA, includes non-traditional information such as genealogy records, a small business centre, and job opportunities listings. Other city libraries in the USA, in Dallas, TX and San Francisco, CA, offer local, state and national government information. 
- Open access Internet points are available in public libraries in Estonia.

- Australia's Gold Coast City Council regularly hosts a two day "Techno Expo" providing customers opportunities to explore and learn all about gadgets, tools and concepts which incorporate the latest technologies.

\subsubsection{Personal development}

'Providing opportunities for personal creative development.'

(Manifesto)

The opportunity to develop personal creativity and pursue new interests is important to human development. To achieve this, people need access to knowledge and works of the imagination. The public library can provide access, in a variety of different media, to a rich and varied store of knowledge and creative achievement, which individuals cannot acquire on their own behalf. Providing access to major collections of the world's literature and knowledge including the community's own literature, is a unique contribution of the public library and still a vitally important function. Access to works of the imagination and knowledge is an important contribution to personal education and meaningful recreational activity. Libraries must extend traditional bibliographic instruction of how to search the catalogue and use print reference tools, to training customers on how to use computers to locate information and evaluate the quality of that information.

The public library can also make a fundamental contribution to daily survival and social and economic development by being directly involved in providing information to people in developing communities; for example, basic life skills, adult basic education and AIDS awareness programmes. In communities with a high illiteracy rate the public library should provide services for non-literates and interpret and translate information where necessary. Basic education regarding how to use the library and its services should also be provided.

- The Rural Audio Libraries of Mali distributed information on hygiene, health, animal husbandry and other topics relevant to people's daily lives. These reached 146 villages, and collective listening sessions were organised. 
- In Bolivia, local libraries are venues for a variety of activities, such as health campaigns, classes in nutrition, mother and baby and youth clubs.

- Employment information centres are offered in some USA libraries. Job seekers can get information about work opportunities and use a variety of media to help prepare for job applications and interviews. These projects can forge links between library staff and the regional government workforce offices.

- A key objective for library services in rural areas of Venezuela was to improve the quality of life of small farmers with limited resources by providing agriculture and animal husbandry information.

- Crandall Public Library in Glen Falls, NY, USA, provided a Health Information Centre complete with a telephone hotline available to answer the public's health questions.

<http://www.crandalllibrary.org/programs/programsconsumerhealth.php>

- London libraries offer a range of books and other resources to help people improve literacy, numeracy and information technology skills.

<http://www.londonlibraries.org/servlets/Ilr/skillsforlife/all>

\subsubsection{Children and young people}

'Creating and strengthening reading habits in children from an early age.'

(Manifesto)

The public library should attempt to meet the needs of all groups in the community regardless of age and physical, economic or social circumstances. However, it has a special responsibility to meet the needs of children and young people. If children can be inspired by the excitement of knowledge and by works of the imagination at an early age, they are likely to benefit from these vital elements of personal development throughout their lives, both enriching them and enhancing their contribution to society. Children can also encourage parents and other adults to make use of the library. It is also important that young people who experience difficulty in learning to read should have access to a library to provide them with appropriate material (see Paragraphs 3.4.2 and 3.4.3). 
- The Central Public Library in Novouralsk, Russia developed a mobile information service focusing on youth entitled, "I am looking for an answer", with the objective of providing immediate information online.

$<$ http://www.publiclibrary.ru/readers/services/virtual-spravkachild.htm>

- "Chitatel.ru or (Reader.ru)" created by the Centralized System of Municipal Libraries, Omsk, Russia targets youth. The online menu offers options to find some 'interesting books and quotes by renowned authors.'

- Centralized Library System of Pskov, Russia, through customer research, identified teenagers as becoming increasingly nonconformist. The library's website, "ABC of "neformal'" <http://www.bibliopskov.ru/neformal/index.htm> explains the essence of teen subcultures, philosophies, psychologies and lifestyles.

\subsubsection{Public libraries and cultural development}

An important role of the public library is providing a focus for cultural and artistic development in the community and helping to shape and support the cultural identity of the community. This can be achieved by working in partnership with appropriate local and regional organisations, by providing space for cultural activity, organizing cultural programmmes and by ensuring that cultural interests are represented in the library's materials. The library's contribution should reflect the variety of cultures represented in the community. It should provide materials in the languages spoken and read in the local community, and support cultural traditions. Libraries should strive to employ staff who speak the languages of the community served.

- Librarians working in Amazonas, Venezuela, were trained to act as intermediaries between different cultures as many people living in the rural communities may only speak and understand their native language.

- The Newark Public Library, NJ, USA, developed the Charles Cummings New Jersey Information Center focusing on local and state history in partnership with the New Jersey Historical Commission. 
- The central libraries of the Republic of Croatia offer library service for all ethnic minorities including books in their mother language, relevant exhibitions, literary and other cultural events, and interlibrary lending to supplement local ethnic needs.

- Australian Gold Coast City Council Libraries celebrate "Cultures on the Coast" with monthly programmes of multicultural interest that are organised and delivered by diverse groups ultimately raising cultural awareness within the community.

\subsubsection{The social role of the public library}

The public library has an important role as a public space and meeting place. This is particularly important in communities where there are few places for people to meet. It is sometimes called 'the drawing room of the community.' Use of the library for research, education, and leisure interests, brings people into informal contact, providing a positive social experience. Library facilities should be designed and built to foster social and cultural activities which support community interests.

- Denmark libraries acknowledge while the traditional use of the Internet for information searching is still the norm, use of the Internet as a communication platform is growing exponentially. A project modelling '23 Things' of the USA Public Library of Charlotte \& Mecklenberg $<$ http://www. plcmc.org/> demonstrates the need for the development of library staff competencies within the social networking web 2.0 area.

<http://splq.info/issues/vol41_2/06.htm>

- Entresse Library, Finland is located in a shopping mall. It is a multicultural library with staff as heterogeneous as its customers. Targeted groups include teenagers and immigrants. Librarians walk through the facility with mobile phones and laptops to provide services to these sometimes difficult to reach populations.

<http://english.espoo.fi//default.asp?path=32373;37337;4 5340;37077;70550;83170 >

- Library 10 is a branch of the Helsinki, Finland, city library, located in the city centre providing innovative services to cus- 
tomers such as the Audio-editing and Rehearsal rooms, where customers can practice or record music. The Stage functions as a venue for cultural performances, discussions, and other exhibits. <http://www.lib.hel.fi/en-GB/kirjasto10/>

\subsection{An agency for change}

In carrying out its role in these key areas the public library is acting as an agency for social and personal development and can be a positive agency for change in the community. By providing a wide range of materials to support education and by making information accessible to all, the public library can bring economic and social benefits to individuals and to the community. It contributes to the creation and maintenance of a well-informed and democratic society and helps to empower people in the enrichment and development of their lives and that of the community in which they live.

The public library should be aware of the issues that are being discussed within the community and provide information that will inform that debate.

\subsection{Freedom of information}

'Collections and services should not be subject to any form of ideological, political or religious censorship, nor commercial pressures.'

(Manifesto)

The public library should be able to represent all ranges of human experience and opinion, free from the risk of censorship. In some countries a Freedom of Information Act (such as the United Stated enacted) will help to ensure these rights are maintained. Librarians and governing bodies should uphold these basic human rights and resist pressure from individuals and groups to limit the material available in the public library.

- In Denmark, libraries encourage citizens to join in political debate and take an active part in democracy through the project, 'The library as democratic hothouse.' In the city of Herning, the library cooperates with local journalists and politicians to create a debating culture which is active on both the Internet and via discussion within the physical space.

<http://splq.info/issues/vol42_1/04.htm> 
- The Australian Library and Information Association believes library and information services have particular responsibilities in supporting and sustaining the free flow of information and ideas. <http://www.alia.org.au/policies/free.access.html>

\subsection{Access for all}

A fundamental principle of the public library is that its services must be available to all and not directed to one group in the community to the exclusion of others. Provision should be made to ensure services are equally available to minority groups who for some reason are not able to use the mainstream services, for example, linguistic minorities, people with physical and sensory disabilities or those living in remote communities who are unable to reach library buildings. The level of funding, development of services, the design of libraries and opening hours should be planned with the concept of universal access as a basic principle (see chapter 3 'Meeting the needs of the customers' and discussion of some national laws which require library compliance for service to disabled populations.)

The development of collections should also be based on the principle of access for all and include access to formats appropriate to specific client groups, for example, Braille and talking books for visually impaired people. Information and communications technology (ICT) should be used to allow access to the library's collections and those of other information sources publicly available on the Internet, from within the library or from remote sites.

\subsection{Local needs}

Public libraries are locally based services for the benefit of the local community and should provide community information services. The services and collections they provide should be based on local needs, which should be assessed regularly. Without this discipline the public library will get out of touch with those it is there to serve and will, as a result, not be used to its full potential. Librarians should, therefore, be aware of the changes in society arising from such factors as social and economic development, demographic change, variations in the age structure, levels of education, patterns of employment and the emergence of other educational and cultural providers (see chapter 6.10, Environmental scanning). 


\subsection{Local culture}

The public library should be a key agency in the local community for the collection, preservation and promotion of local culture in all its diversity. This can be achieved in a variety of ways, for example, the maintenance of local history collections, exhibitions, storytelling, publishing of items of local interest and developing interactive programmes on local themes. Where the oral tradition is an important method of communication the public library should encourage its continuation and development.

- Village Reading Rooms in Botswana served as centres for storing Setswana literature and promoting the Setswana language and for the promotion of culture where discussion groups, traditional songs, dances and meetings are organised.

- In Singapore, an Asian Library Services Unit provides services in the local languages: Chinese, Malay and Tamil.

- In Cuba, libraries may act as venues for poets as well as encourage research into and the conservation of peasant oral traditions.

- "Village Libraries" in India provide a platform for documenting traditional knowledge. Books are published which are written by villagers.

- "Memoria Viva" is a compilation of information about the civil war in Spain housed in Bacelona's libraries.

- Hämeenlinna city library in Finland founded a local history wiki 'Häme-Wiki,' and teaches locals how to edit the wiki. The project is a combination of home town reflections and learning about social media.

<http://www.hamewiki.fi/wiki/Etusivu>

- State Library of Queensland, Australia, provides local studies' standards to maintain and provide access to collections which document the historical development of the local community. <http://www.slq.qld.gov.au/info/publib/policy/guidelines/eight>

- Russian Arkhangelsk Regional Scientific Library provides a portal created as a regional network information resource dedicated to popularizing knowledge about the history and culture of the Arkhangelsk region. All information is concentrated in the thematic sections: "Folklore", "Literature", "Folk arts and crafts," "Theatre", "Visual Arts", "Music", "Architec- 
ture", "Traditions and customs". In each section there are lists of persons and biographical information, along with updated links to Internet resources and reference lists of literature. <http://www.cultnord.ru/>

- The National Library of the Republic of Karelia is a participant in a project for the creation of a distributed system which identifies book monuments in Russia. The project is initiated by the Russian State Library under the federal target programme "Culture of Russia."

<http://library.karelia.ru/cgi-bin/monuments/index.cgi>

- In Spain local history digitalization projects funded by the Ministry of Culture include the open repository $\mathrm{OAI} / \mathrm{PMH}$, and the Biblioteca Virtual de Prensa Historica (Historial Press Virtual Library).

<http://prensahistorica.mcu.es/es/estaticos/contenido.cmd? pagina=estaticos/oai>

- RODA, Repositorio de Objetos digitales y de aprendizaje. RODA is a project offering collections of printed historical matter housed in the Caceres Public Library, containing a total of 118303 colour images, primarily the legacy of Antonio Rodriguez and Mary Monino Brey. <http://roda.culturaextremadura.com>

\subsection{The cultural roots of the public library}

It is important to the long-term success of the library that it should be based on the culture, or cultures, of the country or area in which it operates. It is less likely to succeed if the form and structure of the public library are introduced from a country or area with a very different cultural background. Library management can identify services needed through community surveys of actual and potential customers, public meetings, focus groups and other methods to gather broad-based community input.

- The Centralized Library System Kemerovo created "BiblioVita" to facilitate customers' personal growth and self-knowledge, while secondarily augmenting appreciation of the depth and breadth of library services.

<http://www.kemcbs.com/index.php?page=bv> 
- The Jacksonville Public Library System, FL, USA, <http://jpl.coj.net/res/sites/historyfl.html> offers collections highlighting the history and heritage of the state and special populations such as the African American residents of the area.

\subsection{Libraries without walls}

In developing policies to fulfill the role and purpose of the public library the emphasis should be on the services it provides. In meeting the needs of its community the public library will provide a range of services, some of which (for example, large collections of printed material), can be most effectively delivered from a library building. However, there will be many circumstances where it is more effective to provide the service beyond the walls of the library. Examples will vary in different societies but the principle of planning library development from a service rather than a building perspective is important in all public library policy development. The provision of services using information and communications technology (ICT) also presents exciting opportunities to take library and information services direct to the home and the workplace.

A variety of forms of transport are used to deliver services to sparsely populated areas. The provision of library and information services to people unable to visit a library due to physical or sensory disability or lack of transport, for example, ensures that access to these services is available to all at their home or workplace regardless of their circumstances. These 'mobile library' services are sometimes housed in a van or bus, and as stated provide not only books, but additionally multimedia and increasingly often, Internet access. When these provide the latter the vehicles are sometimes named 'infomobiles.'

- The public library service in Chile developed a variety of mobile services including bookmobiles, book boats, book boxes, backpacks and bicycles. The services offer books and cultural activities for all ages and travel across diverse terrains. They also serve rest homes, hospitals and prisons.

- In Catalonia, Spain a network of mobile libraries provides books, multimedia and Internet access.

- The mobile library of Leppävirta, Finland is a library and community multi-service-centre. There is an Internet workstation, 
healthcare information, stamps for sale, and customers can have medicine, shopping, laundry or heavier mail transported to their home by the mobile library. Customer research prior to building the mobile unit indicated what kind of services the elderly desired.

- Gold Coast City Council, Australia, was the first mobile library of its kind with three extendable pods providing technology centres for adults and children.

<http://www.goldcoast.qld.gov.au/library/t_library.aspx?pid= $7731>$

- Bibliobus is the name for the modern mobile library centre, usually providing updated book collections, providing Internet access, specialised databases and audiovisual facilities for local educational and cultural events. The mobile library allows residents of remote rural areas to access information and educational services, helping overcome the digital divide. Bibliobuses are successfully utilised in the UK, USA, Germany, Finland, and Russia.

<http://www.library.ru/3/focus/bibliobus.php>

- In Ethiopia, donkeys "power" bookmobiles, taking books to outlying villages.

<http://www.ethiopiareads.org/programs/mobile>

\subsection{Library buildings}

Library buildings play an important part in public library provision. These should be designed to reflect the functions of the library service, be accessible to all in the community and be sufficiently flexible to accommodate new and changing services. They should be located close to other community activities, for example, shops and cultural and transportation centres. Wherever possible the library should also be available for community use, for example, for meetings and exhibitions and in larger buildings for theatrical, musical, audiovisual and media performances. A well used public library will make a significant contribution to the vitality of an urban area and be an important learning and social centre and meeting place, particularly in scattered rural areas. Librarians should, therefore, ensure that library buildings are used and managed effectively to make the best use of the facilities for the benefit of the whole community. 
- The Turku main library in Finland embodies $2^{1 \text { st }}$ century architecture which enhances new innovative concepts for the library services provided.

<http://www.turku.fi/Public/default.aspx?nodeid=12503\&cul ture $=$ en-US\&contentlan $=2>$

- Hjørring Central Library is described as Denmark's premiere example of a $21^{\text {st }}$ century public library, and the 'most spectacular and ultimate library place to be.' <http://splq.info/issues/vol41_4/07.htm>

- The new public library building in Kolding, Denmark is situated close to the city centre with a unique view 'to the lake and former castle Koldinghus.' With its transparency, open spaces and light wooden interiors it represents the minimalist continuation of the Scandinavian library style. <http://www.librarybuildings.info/denmark/kolding-library>

- The (more or less) bookless Danish children's library is designed with children very much in mind as well as within the framework of today's knowledge society.

<http://splq.info/issues/vol41_3/07.htm>

- The Russian Library Association provides a portal, "Library buildings: architecture, design, organisation of space"

<http://rba.okrlib.ru/biblioteki/fotogalereya/> offering images of libraries, and building design.

\subsection{Resources}

To fulfill its roles satisfactorily the public library must have adequate resources, not just when it is established but also on a continuing basis, embracing emerging technologies as these enter society to enable it to sustain and develop services that meet the needs of the local community. This means it should provide materials and services in all formats, up-dated regularly to meet the changing needs of groups and individuals, including newly-published and replacement materials and new information technologies as available and which can be supported. It should also provide adequate levels of staff with appropriate training and sufficient funds to support whatever methods of service delivery are needed for it to meet its vital role in the community. Subsequent chapters identify and provide an understanding of resources for optimal public library service. 


\subsection{Value of public libraries}

It is acknowledged that public libraries provide great value to their communities. Value is often defined by what materials and services libraries provide to the communities. In the past public libraries primarily offered access to printed information, and served as a public social and physical meeting place in the community. In the digitized age the role and value of public libraries has become enhanced by the advent of new information technologies. These may include workstations, increased available bandwidth, and provision of computer training. In some communities today, public libraries are the sole provider of free access to the Internet.

The value of public libraries is often discussed around these service provisions. There have been numerous studies that provide economic modelling (see chapter 6 'The Management of public libraries' for some quantifiable performance indicators.)

- A USA library developed an integrated communications public awareness campaign to promote the value of its services via cable television, public service announcements, Web sites, and an interactive TV programme where viewers may "talk" to a live librarian.

- The first comprehensive Australian study of the value which public libraries bring to their communities is entitled "Libraries Building Communities." The report includes views and ideas gathered from over 10000 people via online and print surveys and focus groups.

<http://www.slv.vic.gov.au/about/information/publications/ policies_reports/plu_lbc.html>

\section{Resources}

Aabø, S. (2005). "The role and value of public libraries in the age of digital technologies." Journal of Librarianship and Information Science vol. 37(4), pp. 205-211. (http://lis.sagepub.com/cgi/content/abstract/37/4/205 accessed 1/01/2010).

Berk \& Associates, Inc. (2005). The Seattle Public Library Central Library: Economic benefits assessment.

(http://www.spl.org/pdfs/SPLCentral_Library_Economic_Impacts.pdf accessed 30/12/2009) 
Bertelsen, E., and Cranfield, V. (2001). Act Regarding Library Services. Copenhagen: Danish National Library.

(http://www.bs.dk/publikationer/english/act/pdf/Act_reg_library_ser.pdf accessed 1/01/2010)

Česko. (2003). Law No. 257/2001 Coll. of 29 June 2001 on Libraries and Terms of Operating Public Library and Information Services (Library Act). Prague: National Library of the Czech Republic.

(http://knihovnam.nkp.cz/english/sekce.php3?page=04_Leg/02_LibAct.htm \&PHPSESSID $=3658 \mathrm{c} 047 \mathrm{e} 024 \mathrm{~d} 207 \mathrm{dc} 073 \mathrm{e} 8 \mathrm{bc} 945 \mathrm{a} 775$ accessed 1/01/2010).

Cologne city. (n.d.). World literature: Library literature in Cologne.

(http://www.stadt-koeln.de/5/stadtbibliothek/bibliotheken-archive/literaturwelt/ accessed 1/01/2010).

Cologne Library Association. (n.d.). Cologne Library Association minibib (kiosk in the park). (http://www.foerderverein-stadtbibliothek-koeln.de/ accessed 1/01/2010)

Freedominfo.org. (n.d.). Freedominfo.org: The online network of freedom of information advocates. (http://freedominfo.org/ accessed 1/01/2010).

Goethe-Institut. (n.d.). Sau Paulo - Wissen - Bibliothek - Goethe-Institut: favela projects in Brasil. (http://www.goethe.de/ins/br/sap/wis/bib/deindex.htm accessed 1/01/2010).

Governo do Estado do Paraná. (n.d.). Projects of the Regional Government of Paraná.

(http://www.cidadao.pr.gov.br/

accessed 1/01/2010).

Hage, C. (2004). The public library start up guide. Chicago: American Library Association.

IFLA. (1995). IFLA/UNESCO Public Library Manifesto, The Hague: IFLA. (http://www.ifla.org/VII/s8/unesco/manif.htm accessed 1/01/2010).

IFLA. (1999). IFLA/UNESCO School Library Manifesto.

(http://www.ifla.org/en/publications/iflaunesco-school-library-manifesto-1999 accessed 1/01/2010).

IFLA. (2002). The IFLA Internet Manifesto.

(http://www.ifla.org/publications/the-ifla-internet-manifesto accessed 1/01/2010).

Kekki, K., Wigell-Ryynänen, H. (2009). Finnish Public Library Policy 2015. National strategic areas of focus. Publications of the Ministry of Education. (http://www.minedu.fi/OPM/Julkaisut/2009/kirjasto_ohjelma.html?lang=en accessed 1/01/2010).

Larsen, J., and Wigell-Ryynänen, B. (2006). Nordic public libraries in the knowledge society. København : Danish National Library Authority. 
(http://www.bs.dk/publikationer/english/nnpl/pdf/nnpl.pdf accessed 1/01/2010)

Latimer, K., and Niegaard, H. (2007). IFLA library building guidelines: Developments \& reflections. München: K.G.Saur.

Levin, Driscoll \& Fleeter. (2006). Value for money: Southwestern Ohio's return from investment in public libraries.

(http://9libraries.info/docs/EconomicBenefitsStudy.pdf accessed 1/01/2010)

Library Council of New South Wales, J.L. Management Services, and State Library of New South Wales. (2008). Enriching Communities: The Value of Public Libraries in New South Wales. Sydney: Library Council of N.S.W.

Maine State Library. (n.d.). Library use value calculator. (http://www.maine.gov/msl/services/calculator.htm accessed 1/01/2010).

Mattern, S. (2005). Public places, info spaces: creating the modern urban library. Washington: Smithsonian Books.

MD Brasil Ti \& Telecom. (n.d.). MD Brasil Ti \& Telecom: Sao Paulo, Brazil favela „Monte Azul“ (www.monteazul.com.br accessed 1/01/2010) LINK BROKEN 5.25.2010

Pestell, R., and IFLA Mobile Libraries Round Table. (1991). Mobile library guidelines. Professional report \#28. The Hague: IFLA. (Currently being revised)

Romero, S. (2008). Library Architecture: Recommendations for a comprehensive research project. Barcelona: Colegio de Arquitectos de Catalunya.

SirsiDynix (n.d.). SirsiDynix Institute.

(http://www.sirsidynixinstitute.com accessed 1/01/2010)

State Library of Queensland. (n.d.) Standards and guidelines. (http://www.slq.qld.gov.au/info/publib/build/standards accessed 1/01/2010)

Thorhauge, J. (2002). Danish Library Policy: A Selection of Recent Articles and Papers. Biblioteksstyrelsen. Copenhagen: Danish National Library Authority. (http://www.bs.dk/publikationer/english/library_policy/pdf/dlp.pdf accessed 1/01/2010).

Urban Libraries Council and The Urban Institute. (2007). Making cities stronger: Public library contributions to local development. (http://www.urban.org/uploadedpdf/1001075_stronger_cities.pdf accessed 1/01/2010)

\section{Buildings}

Bisbrouck, M. et al (2004). Libraries as places: Buildings for the $21^{\text {st }}$ century. IFLA Publications Series 109. Munchen: K.G. Saur. 
Bryan, C. (2007). Managing facilities for results: optimizing space for services. Chicago: American Library Association.

Dewe, M., (2006). Planning public library buildings: concepts and issues for the librarian, Aldershot, England: Ashgate.

Hauke, P. (2009). Bibliotheken bauen und ausstatten. Bad Honnef: Bock + Herchen. (http:/ / edoc.hu-berlin.de/oa/books/ree8FL3pymekE/PDF/25Gh3UywL6dIY. pdf)

IFLA Section on Library Buildings and Equipment, Intelligent library buildings: proceedings of the tenth seminar of the IFLA Section on Library Buildings and Equipment, The Hague, Netherlands, 24-29 August, 1997, Marie-Françoise Bisbrouck and Marc Chauveinc (eds), IFLA Publication - 88, Munich, K. G. Saur, 1999

Koontz, C.M. (1997). Library Facility Siting and Location Handbook. Westport, CT: Greenwood Press.

Latimer, K., and Niegaard, H. (2007). IFLA library building guidelines : developments \& reflections. Munich: K. G. Saur.

Niegaard, H., Schulz, K., and Lauridsen, J. (2009). Library Space: Inspiration for building and design. Copenhagen, Danish National Library Authority. 